\title{
Methodological Shortcomings in Hannah Arendt's Conceptualization of Totalitarianism
}

By Antony Kalashnikov

\begin{abstract}
The political philosopher Hannah Arendt was partly responsible for popularizing the term 'totalitarianism'. In doing so, Arendt followed a historicallygrounded, analytical approach, methodically deriving the concept from the cases of Nazi Germany and Stalinist Russia. This essay will argue that Arendt's conceptualization of totalitarianism is imperfect, because of some crucial methodological shortcomings in her analysis. In demonstrating this, I will briefly explicate Arendt's methodology and argument, and critique her concept in so far as it is: grounded in too few cases, the cases are dubiously linked, and the analysis is heedless of a functionalist understanding of ideology.
\end{abstract}

Totalitarianism as a term came into being in the mid-1920's in Mussolini's Italy, and implied the total control of society by the state. ${ }^{1}$ Nowadays, the media uses the concept in much the same way, applying it to regimes exhibiting a high degree of authoritarianism - such as Alexandr Lukashenko's Belarus. ${ }^{2}$ The political philosopher Hannah Arendt was partly responsible for the term's popularization, but her usage of the term is different. In her book Origins of Totalitarianism, she does not approach the term in a definitional way - creating an artificial concept that can be applied to phenomena. Rather, Arendt follows a historically-grounded, analytical approach, methodically deriving the

\footnotetext{
${ }^{1}$ Stanley G. Payne, Fascism: Comparison and Definition (London: University of Wisconsin Press, 1980), 73.

2 James Brooke, "Analysts: Belarus Moves from Authoritarian to Totalitarian," Voice of America, May 3, 2011, accessed May 22, 2011,

http://www.voanews.com/english/news/euro pe/Belarus-Moves-From-Authoritarian-toTotalitarian-121162964.html.
}

concept from the cases of Nazi Germany and Stalinist Russia. This essay will argue that Arendt's conceptualization of totalitarianism is imperfect, because of some crucial methodological shortcomings in her analysis. In demonstrating this, I will briefly explicate Arendt's methodology and argument, and critique her concept in so far as it is: grounded in too few cases, the cases are dubiously linked, and the analysis is heedless of a functionalist understanding of ideology.

Arendt characterizes Origins of Totalitarianism as "[giving] a historical account of the 'elements' which 'crystallized' into totalitarianism... followed by an analysis of the 'elementary structure' of totalitarian movements and domination itself." ${ }^{3}$ To a certain degree, then, the structure of the book expounds her argument in reverse: methodologically speaking, one must first find out 'what totalitarianism is' before its historical

\footnotetext{
${ }^{3}$ Seyla Behabib, The Reluctant Modernism of Hannah Arendt (Thousand Oaks: Sage Publications Inc., 1996), 64.
} 
origins can be discerned. The essence of totalitarianism, thus, is the keystone of her project. Importantly, her concept of totalitarianism is analytical, not definitional, and is derived in the following way. Struck by the unprecedented character of two 1930's regimes - Nazi Germany and Stalinist Russia - Arendt contends that they fail to satisfy any of the traditional regime classifications, such as tyranny, despotism, and dictatorships. ${ }^{4}$ Indeed, they were entirely novel in having "transformed classes into masses, supplanted the party system, not by one-party dictatorships, but by a mass movement, shifted the centre of power from the army to the police, and established a foreign policy openly directed toward world domination." Crucially, they introduced the "radical evil" of the concentration camp system, which "meant the same inexorable doom for human beings as the use of the hydrogen bomb would mean the doom of the human race." In this way, Arendt puts forward a presumptive case for why Nazi Germany and Stalinist Russia should be taken apart and analyzed to glean the elements of the new, totalitarian, regime-type.

Mass propaganda, authoritarian organizational features of society, secret police, and the use of indiscriminate terror were found in both regimes, and already hint at strong similarities. But Arendt's analysis reaches beyond these phenomena and shows them to be merely a manifestation of the essence of

${ }^{4}$ Hannah Arendt, Origins of Totalitarianism (New York: Brace \& World Inc., 1966), 460.

${ }^{5}$ Ibid.

${ }^{6}$ Ibid, 443. totalitarianism - ideology. In Arendt's understanding, it was crucial that the concentration camps, terror, purges, etc. served no utility-function, either in terms of social use or in silencing of opposition. ${ }^{7}$ On the contrary, the teleological, self-consistent totalitarian ideology derives one Law of Movement of human history and applies it directly to society - in particular, either Social Darwinism or Marx's class struggle. Through totalitarian power institutions (most importantly, terror), the Law of Movement becomes realized - the weak are proved weak by being exterminated, people necessarily become class enemies if they are accused of it by the Party. ${ }^{8}$ Totalitarian ideology also seeks to create a One Man out of a society of individuals - so that the hope and freedom implicit in the birth of an individual can be eliminated for the unfettered function of the Law of Movement. ${ }^{9}$ Indeed, ideology is the motivating force of totalitarianism, the unprecedented and definitive feature which separates it from previous tyrannical forms of government.

Reflection may reveal, however, some methodological shortcomings in Arendt's analysis. The paucity of cases she uses in building her argument is problematic, methodologically speaking. Her analysis is entirely based on two historical regimes, Nazi Germany and Stalinist Russia (respectively lasting only 12 and 24 years), from which she derives necessary categories like the Law of Movement, non-utilitarian terror, etc. In

\footnotetext{
${ }^{7}$ Arendt, Origins of Totalitarianism, 440, 444-445.

${ }^{8}$ Ibid, 462-465.

${ }^{9}$ Ibid, 465-466.
} 
several respects, her conceptualization is tied down, narrow, and constrained, forfeiting any further heuristic use for political science. Indeed, in her 1966 "Introduction" to Origins of Totalitarianism, Arendt is apprehensive even about labelling the Chinese communist regime as 'totalitarian' - as it does not entirely fit her list of criteria entirely derived from the two historical cases. ${ }^{10}$ Other more malleable definitions of authoritarian state forms, by contrast, allow for re-application to the current world, such as political theorist Sheldon Wolin's concept of "inverted democracy" in corporatelydominated USA. ${ }^{11}$ Arendt herself writes about the 'permanent revolution' mechanism (whereby the structure of a totalitarian system is constantly reinvented) - which would imply the need for a broader conceptualization of totalitarianism. ${ }^{12}$ Given that Arendt was writing in the late 1940's, if one accepts her contention that totalitarian regimes were an unprecedented phenomenon, it is understandable that her analysis is based on only the first few manifestations. However, the novelty of the totalitarian form is not a given. The political scientist Eric Voegelin, for example, disputes Arendt's assumption, arguing for the "essential sameness" of totalitarianism with similar catastrophes in the past. ${ }^{13}$ In the same vein, political

\footnotetext{
${ }^{10}$ Ibid, x-xii.

${ }^{11}$ Sheldon Wolin, "Inverted

Totalitarianism," The Nation, May 1, 2003, accessed May 22, 2011, http://www.thenation.com/article/invertedtotalitarianism.

12 Arendt, The Origins of Totalitarianism, 389-408.

${ }^{13}$ Shiraz Dossa, The Public Realm and the Public Self: The Political Theory of Hannah
}

theorist John L. Stanley uses Arendt's own categories to show how $19^{\text {th }}$ century Zulu despotism under King Shaka, for one thing, could fit under the definition of totalitarianism. In brief, Shaka's regime had a self-contained, survivalist ideology, a monopoly on power and knowledge, a cult of personality, indiscriminate terror, eugenic and genocidal practices - a veritable Nazism. ${ }^{14}$ Interestingly, Arendt cites his extermination of one million other tribesmen in her work, but does not go further to label it as an example of totalitarianism. ${ }^{15}$ Of course, there were important differences as well, but that is just the point: if totalitarianism is not an unprecedented break with the past, its conceptual categories should be wider, being based on a broader analysis. As it is, Arendt's concept of totalitarianism risks becoming applicable only to historical studies.

Another methodological shortcoming in Arendt's analysis is the dubious link between her two main cases - German Nazism and Stalinism. Critics (such as sociologist Michael Bittman) have been quick to point out the political benefits of conflating Hitler's abhorrent regime with

Arendt (Waterloo: Wilfrid Laurier University Press, 1989), 28-29.

14 John L. Stanley, "Is Totalitarianism a New Phenomenon: Reflections on Hannah Arendt's Origins of Totalitarianism," in Hannah Arendt: Critical Essays, eds. Lewis P. Hinchman and Sandra K. Hinchman (Albany: State University of New York Press, 1994), 19-26.

${ }^{15}$ Arendt, Origins of Totalitarianism, 192193. 
communism. ${ }^{16}$ Although Arendt is certainly not a propagandist, there may be a Cold War bias present in her comparison. Indeed, on a superficial level, The Origins of Totalitarianism is conspicuously lop-sided, which most discussion/examples deriving from the case of Nazi Germany. ${ }^{17}$ This hints at the deeper issue of whether the comparison with Stalinist Russia is acceptable at all. Arendt's comparison hinges on the presumptive similarities the concentration camps, the secret police, the aim for world-domination from which her analysis discerns the ideological commonalities of the two regimes (which is the point of her argument). A brief look at any historiographic studies of the two regimes reveals the complexity in making such comparisons. The exclusive importance and 'agency' of ideology is severely doubted in several interpretations, which instead look to multiple factors as being efficacious within the regimes. The structuralfunctionalist school of the Third Reich, including historians such as Hans Mommsen, argues that Nazi policy did not correspond to any 'ideological intent', but was rather dominated by contradictory and erratic, socioeconomic interests of various elites. Hitler's National-Socialist vision, accordingly, was no more than a propagandistic appeal to the masses. ${ }^{18}$

${ }^{16}$ Michael Bittman, "Totalitarianism: The Career of a Concept," in Hannah Arendt: Thinking, Judging, Freedom ed. Gisela T. Kaplan and Clive S. Kessler (Sydney: Allen \& Unwin, 1989), 58.

${ }^{17}$ Michael Bittman, "Totalitarianism: The Career of a Concept," 65-66.

${ }^{18}$ Ian Kershaw, The Nazi Dictatorship:

Problems and Perspectives of Interpretation
Historians Robert Waith and Rudolph Binion, by contrast, take a psychohistorical approach to the Hitler's Germany - arguing that the leader's "neurotic psychopathy, oedipal complex, monorchism, disturbed adolescence, and psychic traumas" determined the trajectory Nazism took. ${ }^{19}$ In terms of Stalinist Russia, the historian Isaac Deutsher, for example, holds that Stalin's terror and purges served a utilitarian, anti-opposition character, in line with centuries-old Russian political culture. ${ }^{20}$ Economist Alec Nove, in turn, has argued that the terror and use of coercion which accompanied Stalinism's anti-kulak campaign and forced industrialization made economic sense, given that the country felt threatened and needed to rapidly build a powerful modern arms industry. ${ }^{21}$ The point here is not to resolve the historical debate, but rather to recognize that the comparability of Hitler's Germany and Stalin's Russia may not be a given. Superficial commonalities like concentration camps and secret police do not necessarily aid Arendt's analysis if one regime was the expression of a psychopathic maniac, and the other a cruelly-calculating bid for rapid industrialization. Although Arendt does advance certain arguments to prove the ideological motivation for policy (such as the Red Army purges which nearly lost Stalin the Russo-Finnish war), given the scope of her work and her professional

(New York: Oxford University Press, 2000), 78-79.

${ }^{19}$ Ibid, 71-72.

${ }^{20}$ Walter Laqueur, The Fate of the Revolution: Interpretations of Soviet History from 1917 to Present (New York: Macmillan Publishing Company, 1987), 98. ${ }^{21}$ Ibid, 108. 
area, she is not in advantageous position to participate in the debate of historians. In such a way, Arendt's methodology, which relies on an intrinsic similarity between the two cases to conceptualize totalitarianism, may not be justified.

It is understandable why Arendt argues that the essence of totalitarianism is ideology. After all, both the Nazi and Stalinist regimes professed to be ruled by their ideology. In that sense, it is only too easy to take their rhetoric at face value, deducing, for example, the inherent totalitarian aim of world-domination because "evidence that totalitarian governments aspire to conquer the globe and bring all countries on earth under their domination can be found repeatedly in Nazi and Bolshevik literature". 22 This suggests yet another shortcoming in her analysis - the lack of a functional appreciation of ideology. For, having established the presumptive similarities between Nazi Germany and Stalinist Russia, Arendt's analysis interprets them as an expression of a deeper intrinsic commonality - ideology. However, the two regimes policies' may have had other motivations; ideology may have served just another function (legitimation of the Party elite, for example). We thus return to the previous debate, which undermines Arendt's claim that the importance of ideology is a clear fact.To Arendt's defence, it may be said that whether or not ideology was functional is a moot point. If Hitler and cronies carried out a policy, it will never be known whether they were 'carrying out the instructions of the ideology' or were governed by

${ }^{22}$ Arendt, The Origins of Totalitarianism, 415. some other motives. However, there is an asymmetry between Nazi Germany and Stalin's Russia in this argument. Methodologically, it may be fair to draw Nazi ideology from Hitler's actions - at least because it would be very hard (or even impossible) to analytically separate the two, being created by the same person. In the case of Stalin, however, it is less complicated, because he had to work within the framework of Marxism-Leninism; his policies can be measured against it. To say that Stalinism was governed by Marxism's ideological conceptions of class struggle as the Law of Movement, as Arendt does, would necessarily imply that Marxism inevitably leads to it. Of course, Stalinism's ideological polemics paid much lip-service to Marxism and its ideals, claiming, indeed, to be its only true expression. It would be a rather narrow minded view, however, to take this at face value, if only because countless others streams of Marxism have emerged (and already had at the time of Arendt's writing) to contest this, both ideologically and practically. Trotskyites were writing against and fighting the Stalinist legacy. Other communist regimes such as Tito's Yugoslavia both politically distanced themselves and exhibited an alternate institutional form from Stalinism. Perhaps, most importantly, Marxist USSR was able to repudiate Stalinism almost immediately after his death and remain Marxist. ${ }^{23}$ Thus, there is a much more compelling case to Stalinism's use of ideology in the functionalist and rhetoric-value light, and not as an inevitable consequence of Marxism. This, of course, is yet another shortcoming to Arendt's

\footnotetext{
${ }^{23}$ Bittman, "Totalitarianism: The Career of a Concept," 67.
} 
methodology, and by extension, her concept of totalitarianism in which ideology is the essential feature and 'agent'.

In such a way, this essay has sought to reveal some of the problematic areas of Arendt's conceptualization of totalitarianism by the revealing crucial methodological shortcomings in her analysis. Her analysis is grounded in few cases, which limits the heuristic value of her concept of totalitarianism to political science. The cases themselves are dubiously linked, not accounting for the historiography which threatens the validity of Arendt's methodological conflation. Lastly, her analysis is heedless of a functionalist understanding of ideology (which is more historically plausible), threatening the centrality of ideology in her conceptualization of totalitarianism. 


\section{Bibliography:}

Arendt, Hannah. Origins of Totalitarianism. New York: Brace \& World Inc., 1966.

Behabib, Seyla. The Reluctant Modernism of Hannah Arendt. Thousand Oaks: Sage Publications Inc., 1996.

Bittman, Michael. "Totalitarianism: The Career of a Concept." In Hannah Arendt: Thinking, Judging, Freedom, edited by Gisela T. Kaplan and Clive S. Kessler, 5668. Sydney: Allen \& Unwin, 1989.

Brooke, James. "Analysts: Belarus Moves from Authoritarian to Totalitarian." Voice of America, May 3, 2011. Accessed May 22, 2011. http://www.voanews.com/english/news/europe/Belarus-Moves-FromAuthoritarian-to-Totalitarian-121162964.html.

Dossa, Shiraz. The Public Realm and the Public Self: The Political Theory of Hannah Arendt. Waterloo: Wilfrid Laurier University Press, 1989.

Kershaw, lan. The Nazi Dictatorship: Problems and Perspectives of Interpretation. New York: Oxford University Press, 2000.

Laqueur, Walter. The Fate of the Revolution: Interpretations of Soviet History from 1917 to Present. New York: Macmillan Publishing Company, 1987.

Payne, Stanley G. Fascism: Comparison and Definition. London: University of Wisconsin Press, 1980.

Stanley, John L. "Is Totalitarianism a New Phenomenon: Reflections on Hannah Arendt's Origins of Totalitarianism." In Hannah Arendt: Critical Essays, edited by Lewis P. Hinchman and Sandra K. Hinchman, 19-26. Albany: State University of New York Press, 1994.

Wolin, Sheldon. "Inverted Totalitarianism." The Nation, May 1, 2003. Accessed May 22, 2011. http://www.thenation.com/article/inverted-totalitarianism. 